\title{
Jebel Moya: new excavations at the largest pastoral burial cemetery in sub-Saharan Africa
}

Michael Brass ${ }^{1, *}$, Ahmed H. Adam ${ }^{2}$, Dorian Q Fuller ${ }^{1}$, Chris Stevens ${ }^{1}$, Fakri Hassan Abdallah ${ }^{3}$, Iwona Kozieradzka-Ogunmakin ${ }^{4}$, Rayan Mahjoub Jarelnabi Abdallah², Osman Khalil Alawad ${ }^{2}$, Ammar Awad Mohamed Abdalla ${ }^{2}$, Joss Wellings ${ }^{5}$ \& Ali Mohamed Abdelrahman ${ }^{3}$

New excavations at the Jebel Moya cemetery in Sudan reveal extensive evidence for Meroitic-era occupation, providing valuable data on contemporaneous diet, migration, exchange and population composition in sub-Saharan Africa.

Keywords: Sudan, Jebel Moya, Meriotic

Jebel Moya is the largest-known pastoral cemetery in sub-Saharan Africa. Located $240 \mathrm{~km}$ south-south-east of Khartoum, Sudan, it was excavated from 1911-1914 by Henry Wellcome, the founder of the Wellcome Trust. It is a multi-phase site with deposits dating back to $c .5000 \mathrm{BC}$. At 10 ha in size and having yielded more than 3100 human burials, Jebel Moya provides scope for exploring the interactions between local pastoral and external traditions on the southern boundary of the contemporaneous Meroitic state, outside of direct Meroitic political control (Brass 2015, 2016). In October 2017, the University College London-University of Khartoum-National Corporation for Antiquities and Museums expedition to southern Gezira undertook new excavations. A key aim was to perform modern, targeted sampling and recording, and archaeobotanical, artefactual, archaeozoological and osteoarchaeological analyses_including ancient DNA (aDNA), isotopes and AMS dating.

Five trenches were excavated to sample surviving archaeological deposits systematically (Figure 1). Trenches 1, 2 and 4 were excavated in $100 \mathrm{~mm}$ spits and the stratigraphy recorded. Each spit was sampled for archaeobotanical remains. Trench 3 targeted the excavation of an eroding burial (see below).

1 Institute of Archaeology, University College London, 31-34 Gordon Square, London WC1H OPY, UK

2 Department of Archaeology, Faculty of Arts, University of Khartoum, P.O. Box 11115, Khartoum, Sudan

3 Department of Archaeology, National Corporation for Antiquities and Museums, Nile Street, Khartoum, Sudan

4 Faculty of Biology, Medicine and Health, University of Manchester 3.503 Stopford Building, Oxford Road, Manchester M13 9PT, UK

5 Independent Researcher, 71 Holland Street, Kensington, London W14 8HL, UK

*Author for correspondence (Email: michael.brass@ucl.ac.uk)

(C) Antiquity Publications Ltd, 2018 ANTIQUITY 92 365, e6 (2018): 1-6 


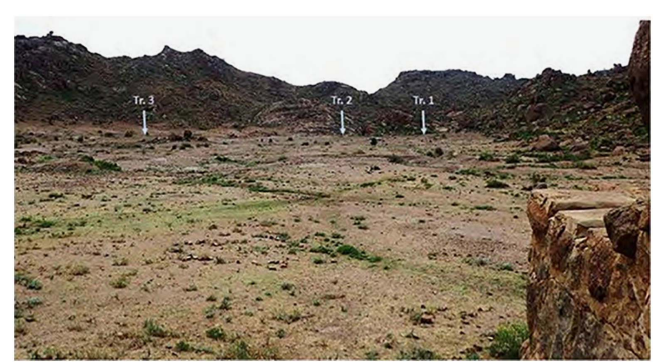

Figure 1. View towards the south-west, indicating the locations of trenches 1, 2 and 3 (courtesy of NCAM).

\section{Trench 1}

Measuring $2 \times 2 \mathrm{~m}$, trench 1 was placed on the western side of the valley, and was excavated to a depth of $0.9 \mathrm{~m}$ (Figure 2). Finds included Meroitic-era ceramics and animal bones, and a horizon of scattered stones (including one quern).

\section{Trench 2}

Measuring $2 \times 2.5 \mathrm{~m}$ (Figure 3), trench 2 was situated near an eroded gully that shows considerable stratigraphic depth. The gully has Late Mesolithic ceramics at the base, followed by Neolithic and subsequently Meroitic-era pottery in reverse order. This was the deepest trench excavated to approximately $1.5 \mathrm{~m}$, with Meroitic-era and Neolithic layers. It was one of the richest in charcoal (recovered through flotation) and finds of all types. Sediment samples for phytoliths were also taken. Apart from a quern, lithics, animal finds and abundant pottery, the finds included a clay (probably a goat) figurine (Figure 4) recovered from below a depth of $1 \mathrm{~m}$. Subject to further

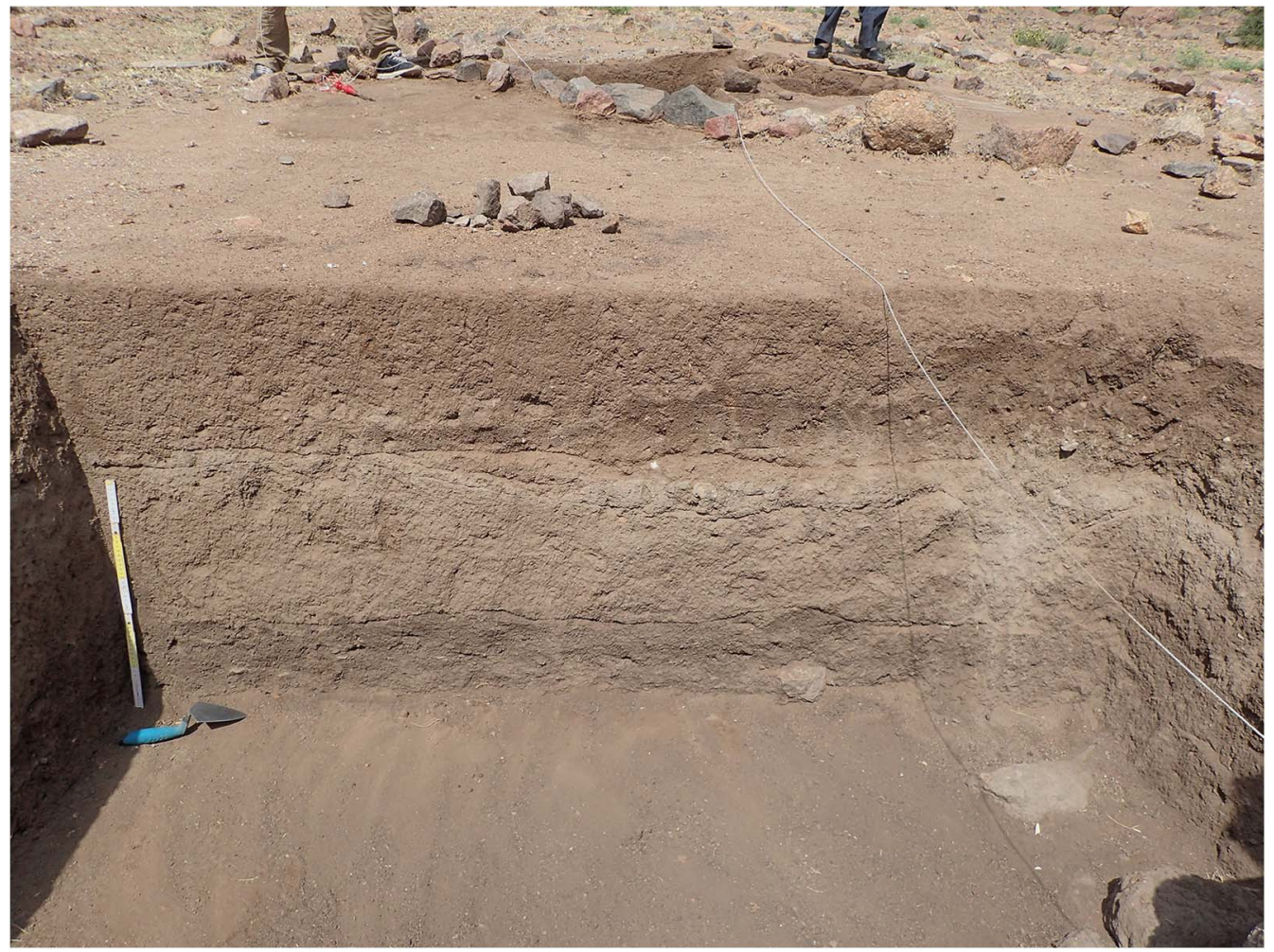

Figure 2. Trench 1 stratigraphy, $0.5 \mathrm{~m}$ scale; the trowel points north (courtesy of NCAM).

(C) Antiquity Publications Ltd, 2018 


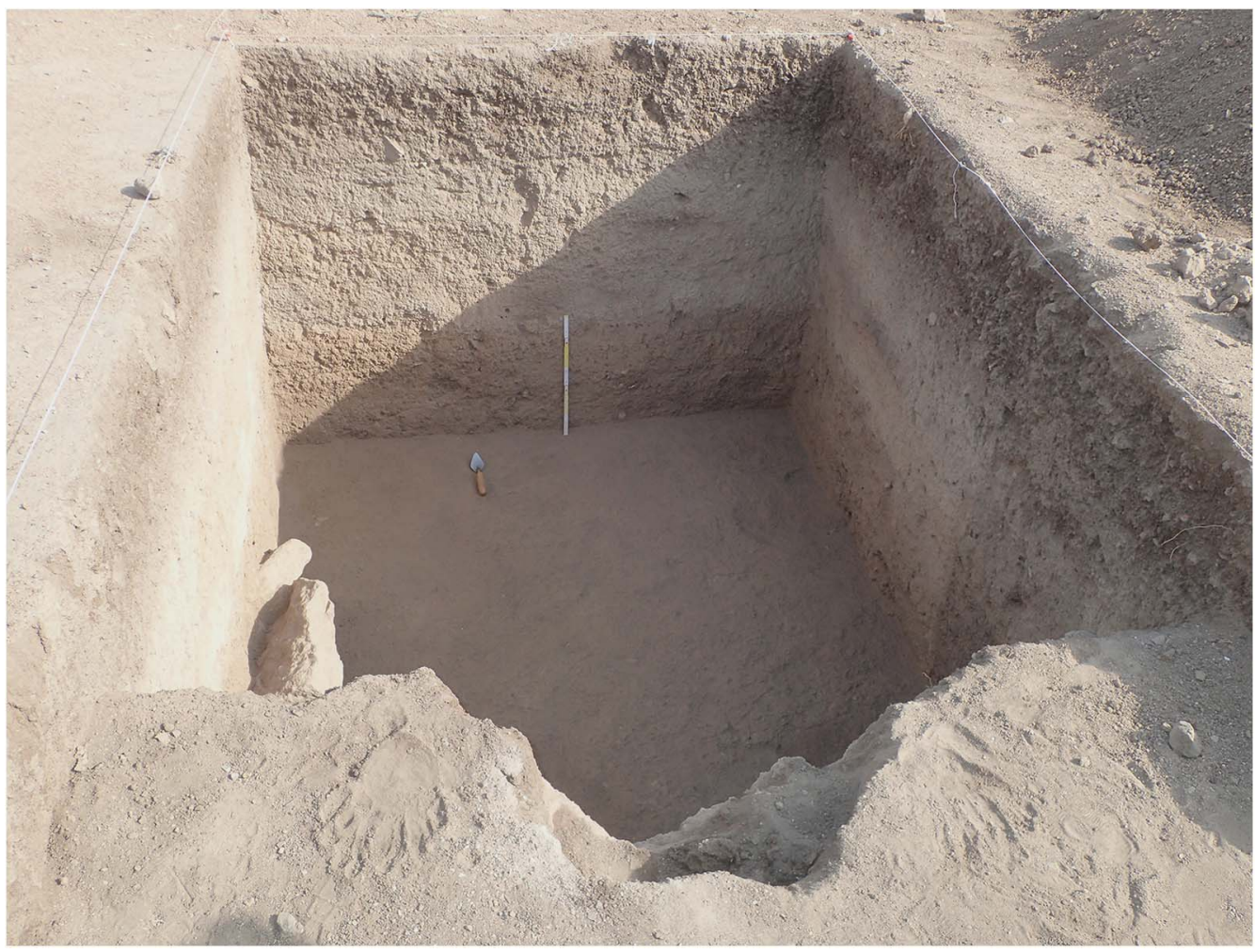

Figure 3. Trench 2 stratigraphy, $0.5 \mathrm{~m}$ scale; the trowel points north (courtesy of NCAM).
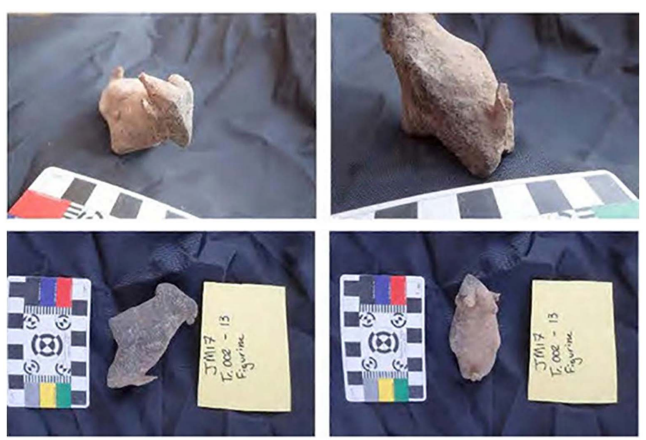

Figure 4. Views of clay figurine, probably depicting a goat, from trench 2 (courtesy of NCAM). investigation, the clay figurine dates to either the early Meroitic era or the preceding Neolithic.

\section{Trench 3}

Trench 3 was situated around a partially exposed burial eroding out of a slope (Figure 5). It contained a probable female aged 25-35 years; the individual was supine, facing right, with the hands placed between the legs. No pathological changes were observed. The dentition was complete, except for ante-mortem loss of the lower-central incisors. Dental attrition was minimal, although advanced labial attrition and surface polishing of the extant incisors could indicate the use of the teeth as a tool. Calculus deposits were observed, mostly on the premolars and molars, and carious lesions affected the right maxillary canine and first premolar. Samples were collected for isotope, radiocarbon and aDNA analyses. 


\section{Trench 4}

Trench 4 was placed near the eastern edge of the site on the southern side of an erosional gully, which had exposed bones (animal) and a large quern, which was later excavated (Figure 6). The trench's sediments contained abundant ceramics and charcoal, as well as

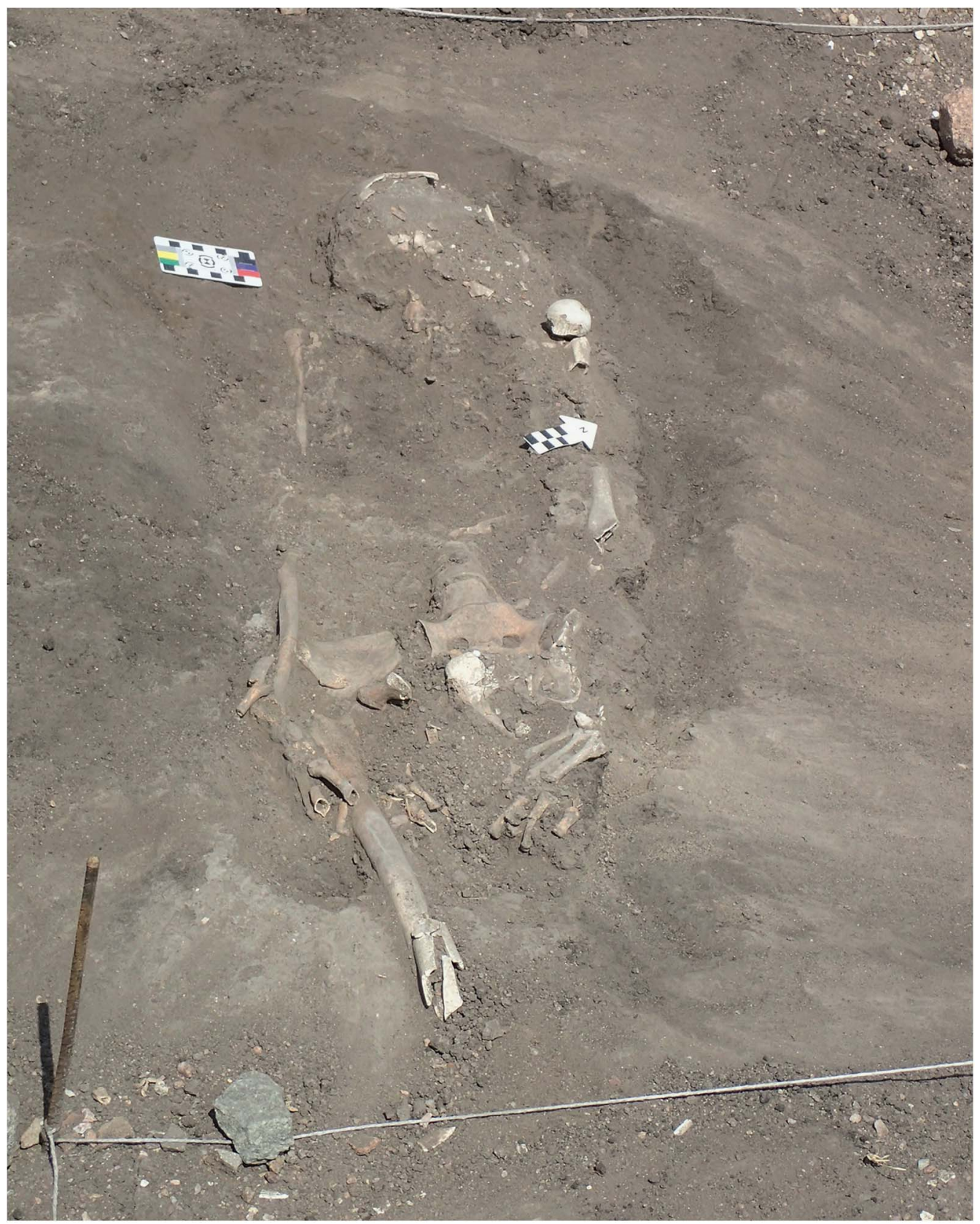

Figure 5. Trench 3 after surface cleaning, with eroding north-west-oriented burial on slope (courtesy of NCAM).

(C) Antiquity Publications Ltd, 2018 
beads and lithics. Sediment samples for phytoliths were taken from both the natural strata and a possible residue on the quern surface.

\section{Trench 5}

Two metres to the west of trench 1 is a stone-ringed tumulus. A $2 \times 2 \mathrm{~m}$ trench encompassed a corner of this tumulus and was deepened to the first compacted surface. No below-ground features or cuts were exposed to confirm this as a burial mound. Current interpretation is that the mound was built on the ground's surface, after the formation of the compacted surface had begun. A ring of stones was then placed around the mound.

\section{Flotation and wet-sieving programme}

Systematic flotation was performed on 40 samples using a washover bucket method through a 250 micron mesh. This yielded charcoal, seed and fruit remains. They are being analysed at UCL's archaeobotany laboratory.

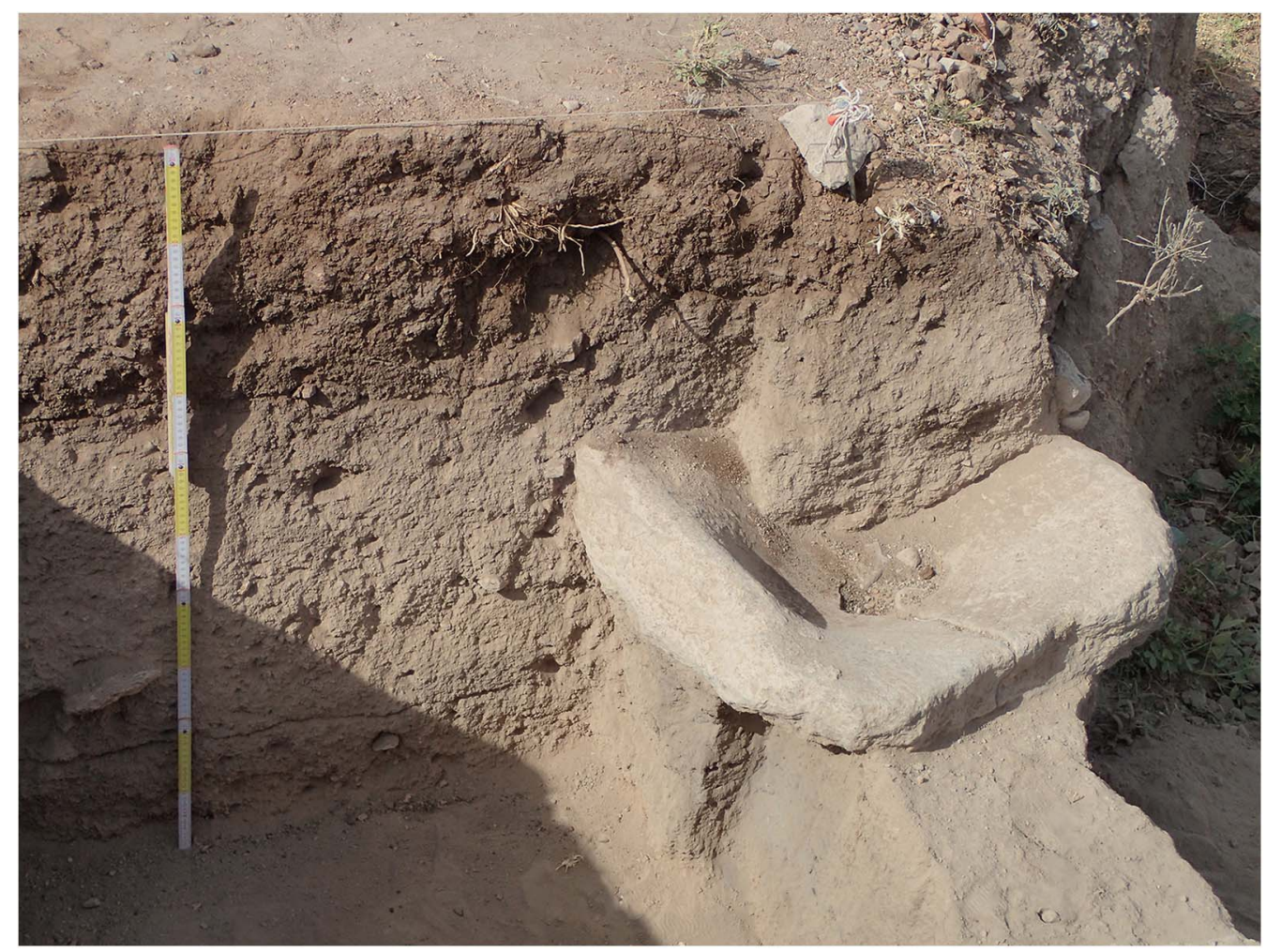

Figure 6. Trench 4, east-facing section at the end of the excavations, including a massive quern (courtesy of NCAM).

(C) Antiquity Publications Ltd, 2018 


\section{Conclusion}

This is the first time that occupational units at Jebel Moya have been properly excavated and documented. The scarcity of African pastoral burial complexes and the size of Jebel Moya make this a very valuable archaeological resource. Jebel Moya offers valuable information on diet, landscape movements, exchange and population composition.

\section{Acknowledgements}

We wish to thank the Society for Libyan Studies for its generous grant for the research and the 2017 field season. The archaeobotanical and bioarchaeological analyses were funded by the European Research Council (grant 323842) and the European Union's Horizon 2020 research and innovation programme under the Marie Skłodowska-Curie (grant agreement 665778), respectively. We are also grateful to Andy Bevan, Sue Hamilton, Kevin MacDonald, Scott MacEachern and Isabelle Vella Gregory for their expertise and support, as well as the British Museum and NCAM.

\section{References}

BRASS, M. 2015. Interactions and pastoralism along the southern and southeastern frontiers of the Meroitic state, Sudan. Journal of World Prehistory 28: $1-34$. https://doi.org/10.1007/s10963-015-9089-1
- 2016. Reinterpreting chronology and society at the mortuary complex of Jebel Moya (Sudan) (Cambridge Monographs in African Archaeology 92). Oxford: Archaeopress. 